\title{
The probability of leaving a low-paid job in Spain: The importance of switching into permanent employment
}

\author{
Maite Blázquez ${ }^{1}$ \\ Universidad Autónoma de Madrid \\ Received 28 February 2006; accepted 5 October 2006
}

\begin{abstract}
This paper is aimed at analyzing the opportunities of getting a better paid job for those workers at the bottom of the earnings distribution. For this purpose I use the European Community Household Panel Survey (ECHP, 1995-2001), from which a sample of Spanish workers aged 16-64 years old has been drawn. The econometric technique consists of a Heckman selection probit model that allows me to account for the endogeneity of initial conditions. Results show that switching into permanent contract, either when remaining with the current employer or when changing employer significantly increases the likelihood of leaving a low pay situation.
\end{abstract}

JEL Classification: J30, J41, J60

Key words: Low-wage employment, job mobility, type of contract, Heckman probit.

\section{Introduction}

The economic and institutional changes experienced by many industrialized countries over the last decades have influenced the distribution of wages both over time and among different groups of

1 Author for correspondence: maite.blazquez@uam.es. The elaboration of this paper started while being affiliated as a postdoctoral researcher to the AIAS Universiteit van Amsterdam. I would like to thank Wiemer Salverda and an anonymous referee for useful comments and suggestions. The usual disclaimer applies.

(C) Revista de Economía Laboral 
individuals in the labour market. In most European countries the distribution of earnings has become more dispersed giving rise to increased analysis of those workers who are considered to be low paid. This naturally has stressed the need for dynamic analytical approaches to address the question whether particular individuals or groups are trapped in low-paid segments of the labour market, or whether low pay is a transitory phenomenon.

The extent of low pay at any point in time is a cause of concern as it measures the proportion of workers lagging behind in the wage distribution with negative consequences for their relative living standards and social inclusion. It is also important for the economy as a whole inasmuch at it signals the corresponding extent of low productivity or low paid jobs. The issue becomes even more crucial in a dynamic context, in the case of workers that are trapped in low paid jobs and do not have the prospect of a career that evolves over time. In fact, from the perspective of individual workers, their earnings level and its evolution over the course of their working lives are important determinants of their level of economic well-being.

Apart from the significant changes in the distribution of earnings, major changes in the distribution of employment and unemployment also occurred in the labour force, with declining employment rates and growing joblessness in many European countries. In this context, some have argued for the existence of a (negative) trade-off between the extent of joblessness and the overall wage dispersion, advocating for greater labour market flexibility to reduce unemployment. In fact, the growing interest in the development of low-wage employment in Europe in the last twenty years has firstly been due to the prospect of reducing unemployment through the creation of large number of low-paid, low-skill jobs.

Among European countries, Spain is well known for displaying one of the highest unemployment rates, with an average unemployment rate close to $20 \%$ in the mid 1980s and the beginning of 1990s. Employment creation has been one of the major issues that Spanish governments have been confronted with since the 1980. In 1984 the tripartite Economic and Social Agreement (AES) introduced a wide range of measures for temporary employment, which have probably been responsible for the good record of employment creation that came about between 1984 and 1991. These employees with non-standard work arrangements, particularly those on fixed-term contracts, have often been found to have lower wages than their counterparts holding open-ended work contracts (Bentolila and Dolado, 1994; Castillo and Toharia, 1993; Jimeno and Toharia, 1993, 1996; de la Rica and Felgueroso, 1999; Pérez and Hidalgo, 1999). More recently, Davia and Hernanz (2004) also find evidence of a 
clear wage gap in favour of permanent workers. However, these authors find that these wage differentials have a strong composition effect: permanent and temporary workers are different and work on different tasks. The work of Amuedo-Dorantes and Serrano-Padial also finds that temporary workers earn significantly less than their permanent counterparts at a given point in time. But, at the same time, these workers also experience greater wage growth, so that their earnings quickly improve.

This paper is aimed at analyzing the main factors determining the probability of leaving a low pay situation. Special attention is given to the role of job mobility and changes in the contractual arrangement. In this respect, the results reveal that switching into permanent employment, either when continuing with the same employer or when changing employer, significantly increases the individual likelihood of getting a better paid job.

The remainder of the paper is as follows. The next section provides a short review of the previous literature on low-wage employment. Section 3 discusses how to define low pay. Section 4 illustrates the data set used, while Section 5 analyzes the characteristics of low-paid workers and jobs. Section 6 describes the econometric model while Section 7 presents the main results. Finally, Section 8 concludes.

\section{Previous literature}

Low-wage employment has been a focus of research and policy interest both at a macro level, and from a micro perspective (OECD, 1996; Asplund et al., 1998; Lucifora and Salverda, 1998; Salverda et al., 2000; Marx and Salverda, 2005). Most of these works have paid particular attention to differences between some European countries and the USA regarding the incidence of low-wage employment.

Recently, the European Commission has provided some comparative data about the incidence of low-wage employment among the European countries ${ }^{2}$. The study provides evidence of little variation in the incidence of low pay between 1995 and 2000, with a decrease from $15.6 \%$ in 1995 to $14.9 \%$ in 1998 , rising again but only marginally in 1999 and 2000 to $15.1 \%$. However, there exist wide variations between different Member States, with the highest incidence of low pay

2 European Community: "Labour market transitions and advancement: temporary employment and low pay in Europe", chap 4, in Employment in Europe, 2004. See Table 1. 
in the UK and Ireland (19.4\% and $18.7 \%$ respectively in 2000$)$, and lowest in Denmark and Italy (8.6\% and $9.7 \%$ respectively). The analysis also reveals a marked decline of the incidence of low-wage employment in Spain (from 18.9\% in 1995 to $15.6 \%$ in 2000) and Portugal (from $14.4 \%$ to $10.9 \%$ ), while the Netherlands and Germany have experienced an appreciable increase (from 13.3\% in 1995 to $16.6 \%$ in 2000 in the Netherlands, and from $13.9 \%$ in 1998 to $15.7 \%$ in 2000 in Germany).

Table 1: The incidence of low pay by country and year (percentages)

\begin{tabular}{ccccccc}
\hline Country & 1995 & 1996 & 1997 & 1998 & 1999 & 2000 \\
\hline Germany & 14.3 & 13.9 & 13.8 & 13.9 & 15.0 & 15.7 \\
Denmark & 9.0 & 8.6 & 8.9 & 8.6 & 8.8 & 8.6 \\
Netherlands & 13.3 & 14.4 & 15.4 & 15.6 & 15.8 & 16.6 \\
Belgium & 13.4 & 12.9 & 13.2 & 12.9 & 12.4 & 12.2 \\
France & 15.8 & 15.5 & 15.4 & 15.5 & 16.2 & 15.6 \\
UK & 20.9 & 20.6 & 20.0 & 19.4 & 19.4 & 19.4 \\
Ireland & 21.8 & 21.7 & 21.6 & 21.2 & 20.2 & 18.7 \\
Italy & 10.4 & 10.1 & 9.9 & 10.0 & 9.8 & 9.7 \\
Greece & 16.1 & 15.4 & 15.7 & 15.5 & 15.8 & 16.0 \\
Spain & 18.9 & 18.5 & 17.8 & 16.9 & 16.0 & 15.6 \\
Portugal & 14.4 & 13.6 & 12.9 & 12.7 & 11.8 & 10.9 \\
Austria &. & 13.9 & 12.4 & 12.2 & 11.5 & 11.2 \\
Finland &. & & 11.3 & 11.4 & 11.0 & 10.8 \\
Total & 15.6 & 15.3 & 15.0 & 14.9 & 15.1 & 15.1 \\
\hline
\end{tabular}

Source: Employment in Europe. "Labour market transitions and advancement: temporary employment and low pay in Europe", chap 4.

Previous research has also examined the link between low pay and wage-setting institutions (Blau and Kahn, 1996; Gregory and Sandoval, 1994; OECD, 1996, 1998; Rubery and Fagan, 1993). In a recent work, Lucifora et al. (2005) review the patterns of low pay in Europe and show that union density, collective bargaining coverage and the structure of wage negotiations jointly contribute to reduce the incidence of low pay. Other papers have analysed the relationship between low pay and employment creation, competitiveness, technology and minimum wages (Card and Krueger, 1995; Dolado et al., 1996; Fernie and Metcalf, 1996; Machin and Manning, 1996; Schechter, 1993; and Shaheed, 1994).

Recent research on low paid employment underlines the need of a longitudinal analysis of the phenomenon (Stewart and Swaffield, 1999; Dickens, 2000, Cappellari, 2004). Evidence on the degree of mobility across the low pay threshold from one period to another can 
reveal to what extent low pay is a transitory or prolonged episode of earnings careers. To the extent that low pay is a transient phenomenon, involving individuals who are experiencing a temporary setback, or young workers acquiring skills and experience that will enhance their future earnings, the situation is self-limiting. But when workers are trapped in low-paid jobs and economic disadvantage becomes a persistent characteristic, serious issues of inequality and welfare arise. In this line, the work of Simón et al. (2004) shows that low-wage employment in Spain is significantly related to the poverty situation of Spanish households, and that this relationship is reinforced if who holds the low-wage employment is the head of the family.

Sloane and Theodossiou (2000) find substantial upwards earnings mobility among younger men and the better educated, but they find that low pay seems to be more persistent for a substantial number of workers, particularly women, older men and the less qualified. For Britain, Gregory and Elias (1994) found that there is considerable mobility out of the bottom of the wage distribution, especially by younger men. Asplund et al. (1998) estimate the year-toyear upward mobility of low-wage earners in Denmark and Finland, and find that men in low-paid employment are more downwardly mobile than women, but acquiring occupation specific skills and other human capital tends to be related to upward mobility. However, Van Opstal et al. (1998) found that in the Netherlands the accumulation of firm-specific human capital contributes far less to earnings upward mobility than does general experience. For the UK, Gosling et al. (1997) find that not only does human capital assist upward earnings mobility but also that the most important determinant of movement out of low pay is job tenure. Finally, Arai et al. (1998) find that there are typical low-paid occupations. In a study for Finland, Norway and Sweden, these authors find that occupation is revealed to be more important than an individual's human capital endowments or industrial affiliation. Furthermore, they also examine to what extent workers appear to be trapped in these low-paid occupations.

\section{Measure of low pay}

Measurement of the incidence of low pay will be sensitive to: i) the way low pay is defined; ii) the earnings concept used; and iii) whether fulltime and/or part-time workers are included. However, economic theory does not provide us with any detailed reasoning on how low pay should be defined. The definition of low pay is in some sense arbitrary and several 
approaches have been used in the literature (CERC, 1991; OECD, 1996 a). Low pay may be defined in absolute or relative terms. Using a measure such as the lowest decile, quintile or third decile has the effect of accounting for a fixed percentage of all workers. The alternative of defining low pay as a percentage of median earnings allows for variations in the proportion defined as low-paid over time, and therefore is more suitable for studying whether low-employment is a temporary or permanent phenomenon.

Proposed low pay thresholds are typically expressed as some fraction of either the mean or the median. In this paper I define workers in low-paid jobs as those earning less than two-thirds of the median. In addition, low pay is measured in terms of hourly gross earnings. Focusing on hourly earnings has a number of advantages. In particular, it allows both full-time and part-time employees to be included and compared on a meaningful basis.

\section{Data}

Longitudinal data are essential to conduct both cross-sectional and dynamic analysis. In this paper I use data from the European Community Household Panel (ECHP), which forms the most closely co-ordinated component of the European system of social surveys. This survey gathers information of several socio-economic aspects in the European Union. It occupies a central position in the development of comparable social statistics across Member States on income including social transfers, labour poverty and social exclusion, housing, health, as well as various other indicators relating to the living conditions of private households and persons. It is, therefore, a harmonized longitudinal survey that makes it possible to follow up and interview the same private households and persons over several consecutive years.

As for the type of information I will need in the analysis, the ECHP is provided with information on characteristics of jobs such as the type of contract, the date starting with the current employer, occupation, size of the firm, public or private employer, whether is full-time or part-time, and monthly (both gross and net) wage.

The analysis is based on the 1995-2001 waves of the ECHP for Spain. The selected sample consists of wage and salary workers aged between 16 and 64 years old, working more than 15 hours per week ${ }^{3}$,

${ }^{3}$ I focus the analysis on the seven latest waves of the survey since the type of contract is not observed in the 1994 survey. Furthermore, people working less 
who are observed at least two consecutive years, and for whom I have information on earnings, type of contract and the year when started with the current employer. Hourly earnings are derived using variables PI211MG (current wage and salary earnings - gross (monthly)) and PE005A (how many hours (including paid overtime) do you work in your main job or business). And for every year, from 1995 to 2001, I compute the low pay threshold as the two thirds of the median earnings over the whole sample of wage and salary earnings aged between 16 and 64 years old and working more than 15 hours per week.

Based on the observed changes in the contractual arrangements between two consecutive years, I can distinguish four types of transitions. We refer to "P-P" and "T-T" transitions when individuals remain employed under permanent and temporary contracts, respectively. And "P-T" and "T-P" transitions include those workers who experience a change in the type of contract from permanent to temporary and from temporary to permanent, respectively. Finally, the survey also allows me to distinguish between those who remain with their current employer, "stayers", and those who change jobs between the survey dates, "movers". Combining job mobility and changes in the contractual arrangement I can then construct eight different categories of transitions: SPP, SPT, STT, STP, MPP, MPT, MTT, and MTP. ${ }^{4}$

\section{Descriptive analysis}

In this section I first analyze the characteristics of either, workers and jobs, that are more closely related to low wage rate and how the pattern of low-wage employment has evolved over time.

\subsection{Characteristics of low-paid workers}

Figure A1 presents the evolution of low-wage employment by

than 15 hours per week are not included in the analysis since information on the number of hours worked in a week is not available for them, and this represents a very small group in the total sample. Self-employed and unpaid family-employed workers are not included in the analysis.

${ }^{4}$ In principle, it would be expected that SPT category was not observed. However, it could be possible that worker was laid off for a short period of time, for example due to a negative shock in the demand of the product, and then hired again by the same employer on a temporary basis, so that the worker might report that he/she has changed from permanent to temporary employment while continuing within the same firm. 
gender. Females are clearly more likely to suffer from a low pay situation. Furthermore, the gender differences become larger at the end of the period under analysis. In 1995, 24\% of females were employed in a low-paid job, while the corresponding percentage for males was less than 15\%. In 2001 the corresponding percentages were $22 \%$ and $9.6 \%$ for females and males respectively.

In Figure A2 I report the evolution of low-wage employment for different age groups. In particular, I consider three different age groups: people aged between 16-29 years old, those aged 30-49 years old, and those between 50-64 years old. Comparisons across the age cohorts show a remarkably higher incidence of low-wage employment amongst the youngest cohorts. This is not surprising since the Spanish youth labour market is characterized by low wages relative to adults, as well as high relative rates of unemployment. Furthermore, we observe that the differences between young and adult workers become smaller after 1997. This result can be linked to the substantial rise in the ratio between youth and adult minimum wages that has gone from $40 \%$ before 1990 to $77 \%$ in 1995 and to $89 \%$ in 1997 , the latter increase due to the agreement of equalizing teenage minimum wage to the adult level.

These previous results confirm that females and young workers in Spain not only are the most affected by the highest unemployment rates but they also suffer from a higher incidence of low pay. In this sense, we can set out that both females and young workers may be considered as disadvantaged groups in the Spanish labour market.

Finally, Figure A3 shows the evolution of the percentage of people falling below two-thirds of the median earnings by different educational levels: primary, secondary and tertiary education. As expected, individuals with just primary education completed are the most likely of being in a low-paid job, while those with tertiary education completed exhibit the lowest incidence of low pay. In 1995, for instance, around $25 \%$ of people with primary education were in a low-paid job, while the corresponding percentage for those with tertiary education was around $5 \%$, and these differences remain more or less unchanged over the whole period.

\subsection{Characteristics of low-paid jobs}

As concerned job characteristics, I first analyse the evolution of low-wage employment by different types of firm. I first distinguish between public and private sector, and then, within the private sector, between small (less than 50 employees), medium (50-500 employees) and large firms (more than 500 employees). As it can be observed in Figure A4, clear differences become apparent between the different types of firms. 
Small private firms are clearly the most likely to have a high incidence of low pay. In contrast, the lowest incidence of low-wage employment occurs in the public sector ${ }^{5}$. These differences remain quite significant over the whole period. However, one can notice a decrease in the incidence of lowwage employment in small private firms (from about 25\% in 1995 to $20 \%$ in 2001) while for the public sector the percentage remains unchanged (around 5\%).

In Figure A5 I distinguish between part-time and full-time jobs. Overall, low-wage employment is found to be more likely among parttimers. However, the incidence of low-wage employment among part-time workers is quite unstable. This could be linked to the profile of this type of wage earners and the effects of the 1994 and 1997 reforms. According to the Social and Economic Council report ${ }^{6}$, which was based on data derived from the Labour Force Survey (EPA), most of part-time workers are married women over 30 years of age. They also have a low level of education and find employment in the least skilled sectors, mainly domestic services, retail and catering. With the 1994 reform there was an appearance of part-time employment amongst women with a higher level of education. In contrast, male part-time employment is less significant, and male part-time workers tend to be young. Also, the higher the level of education and qualification, the greater is the tendency towards part-time employment among men. Another important change relating to part-time employment was introduced by the "April agreements" of 1997: part-time work has been redefined as "employment in which the number of hours is less than that of comparable full-time workers (i.e. in the same company or covered by the same collective agreement)".

Differences in the evolution of low-wage employment by the type of contract are shown in Figure A6. As it can be observed, workers employed on a temporary basis are much more likely to suffer from low pay, than those holding a permanent contract. Around $25 \%$ of people employed with a temporary contract are low-paid, while the corresponding percentage amongst those employed on a permanent basis is always less than $10 \%$.

Figures A7a - c reveal that the percentages of low-paid workers vary greatly by occupation. The lowest percentages are found among legislators, senior officials and managers and professionals, with less than

\footnotetext{
${ }^{5}$ A possible explanation for the lowest percentages of low-paid in the public sector is that from 1986 to 1992, Spanish public administration went through a phase of decentralization in which many secure well-paid civil servant jobs were created for both men and women.

6 Social Economic Council report. "El trabajo a tiempo parcial". September 1996.
} 
$5 \%$ of people employed in these occupations suffering from low pay. In contrast, people employed in skilled agriculture and fishery workers; service workers and shop and market sales workers; and those in elementary occupations show the highest incidence of low-wage employment.

Finally, Figures A8a - c explore industry variations regarding the incidence of low pay. The figures show remarkable sectorial variations in low pay, which is a common feature of countries with deregulated labour markets and uneven collective bargaining. In Figure A8a sectors with the highest incidence of low-wage employment are reported. This corresponds to: agriculture, wholesale and retail trade, repair of motor vehicles, motorcycles and personal/household goods; hotels and restaurants; and other community, social and personal service activities, private households with employed persons, extra-territorial organizations and bodies. In contrast low-wage employment is less likely among: financial intermediation; public administration and defense, compulsory social security; and education (see Figure A8c).

\section{Econometric model}

From the welfare point of view, it is important to address the question whether low pay is a transitory phenomenon of a worker's life, as predicted by the human capital theory, or whether it is a more serious and long lasting problem. This section is aimed at analysing the main factors determining the individual likelihood of leaving a low-paid job. For this purpose I adopt an econometric approach based on yearly transitions, and I estimate the probability that an individual in a low pay situation in period $t$ moves into a better paid job in period $t+1.7$

If initial conditions were exogenous a standard probit model would be applied. However, if being initially low-paid is not exogenous, the estimated results obtained from a standard probit model would be biased. To account for this selection bias I use a Heckman probit selection model. A similar econometric framework to address the initial conditions problem when analysing the transition probabilities at the bottom of the earnings distribution has been used by Stewart and Swaffield (1999) and Cappellari (2004). In Stewart and Swaffield (1999) a bivariate probit model with endogenous selection is used to estimate low pay transitions, while in Cappellari (2004) the analytical framework is characterised by the ability to account for the endogeneity of initial conditions and earnings attrition. In this paper, the issue of attrition is not fully addressed, as in Cappellari

7 This obviously implies that an individual can be observed more than once. 
(2004), but the longitudinal analysis is done using the normalised base weight for interviewed sample persons (variable PG003).

The conditional probability of leaving a low-paid job given that the individual is initially in a low pay situation is given by:

$$
\operatorname{Pr}\left(y_{i 2}=1 \mid y_{i 1}=1\right)=\frac{\Phi_{2}\left(x_{i 2}^{\prime} \beta_{2}, x_{i 1}^{\prime} \beta_{1}, \rho\right)}{\Phi\left(x_{i 1}^{\prime} \beta_{1}\right)}
$$

where $y_{i 2}=1$ if the individual $i$ leaves a low pay situation and switches to a better paid job, $y_{i 1}=1$ if the individual $i$ is initially in a low-paid job, $x_{i 1}$ is the vector of factors that determines the probability of low pay (gender, marital status, dummies to identify whether the individual is the responsible for accommodation and whether lives in a couple with dependent children, age, education, type of contract, on-the-job training, dummies to identify part-time employment and the first job, a dummy to identify individuals with previous unemployment experience of one year or more, and a set of occupational dummies), $x_{i 2}$ is the vector of factors that influences the likelihood of leaving a low pay situation (gender, age, education, dummies to identify switching contract or/and employer ${ }^{8}$, onthe-job training, first job, type of firm, a dummy to identify employment durations of 3 years or more ${ }^{9}$, and a set of occupational dummies), $\Phi$ is the univariate standard normal cumulative distribution function, $\Phi_{2}$ is the cumulative distribution function of the bivariate standard normal, $\beta_{1}$ and $\beta_{2}$ are the vectors of parameters to be estimated, and $\rho$ denotes the correlation coefficient.

In the special case where $\rho=0$ the conditional probability of leaving a low-paid job can be modelled using a standard probit approach. In contrast, if $\rho$ is non-zero the more general model given by equation (1) is required and identification restrictions are needed to make the model credible. The latest implies the inclusion of some different explanatory variables in $x_{i 1}$ and $x_{i 2}$. The model is estimated by maximum likelihood. The log likelihood function would be as follows:

\footnotetext{
8 These explanatory variables refer to transitions between $t$ and $t+1$, while the rest of static explanatory variables included in the transition equation are referred to period $t$. In both cases, $t$ refers to the same year.

${ }^{9}$ I can not observe spell durations in low-wage employment, but I can observe employment duration in the current job.
} 


$$
\begin{aligned}
& \ln L\left(\beta_{1}, \beta_{2}, \rho\right)=\sum_{y_{1}=1, y_{2}=1} \ln \Phi_{2}\left(x_{i 2}^{\prime} \beta_{2}, x_{i 1}^{\prime} \beta_{1}, \rho\right)+ \\
& \sum_{y_{1}=1, y_{2}=0} \ln \Phi_{2}\left(-x_{i 2}^{\prime} \beta_{2}, x_{i 1}^{\prime} \beta_{1},-\rho\right)+\sum_{y_{1}=0} \ln \Phi\left(-x_{i 1}^{\prime} \beta_{1}\right)
\end{aligned}
$$

\section{Main results}

Table 2 presents yearly transitions for the period 1995-2001 and for the whole sample of individuals aged between 16 and 64 years old. The transition analysis includes the following labour market states: low-paid jobs; jobs above the low pay threshold; employment of less than 15 hours per week; self-employment and unpaid family work; unemployment; and inactivity. ${ }^{10}$ As can be observed, $39.2 \%$ of the total amount of labour market transitions corresponds to individuals initially employed as wage and salary workers working more than 15 hours per week. Of this amount, 7.1 per cent are workers in low-paid jobs, while the remaining 32.1 per cent corresponds to workers earning more than two thirds of the median earnings. Inactivity represents the second most common outcome $(36.6 \%)$, while unemployment and, self-employment and unpaid family work represent the $11.6 \%$ and $11.3 \%$, respectively. Finally, only $1.3 \%$ of the total sample corresponds to wage and salary workers working less than 15 hours per week.

Table 2: Yearly transitions total sample (ECHP-Spain, 19952001)

\begin{tabular}{cccccccc}
\hline & $\begin{array}{c}\text { Low } \\
\text { pay }\end{array}$ & $\begin{array}{c}\text { No low } \\
\text { pay }\end{array}$ & $\begin{array}{c}\text { Employee } \\
<15 \mathrm{~h}\end{array}$ & $\begin{array}{c}\text { Self-employed } \\
\text { +Unpaid } \\
\text { family work }\end{array}$ & Unemployed & Inactive & Total \\
\hline $\begin{array}{c}\text { Low pay } \\
\text { No low pay }\end{array}$ & 0.029 & 0.024 & 0.001 & 0.002 & 0.009 & 0.006 & 0.071 \\
$\begin{array}{c}\text { Employee } \\
\quad<15 \mathrm{~h}\end{array}$ & 0.001 & 0.002 & 0.003 & 0.000 & 0.003 & 0.004 & 0.013 \\
$\begin{array}{c}\text { Self-employed } \\
\text { + Unpaid } \\
\text { family work }\end{array}$ & 0.002 & 0.008 & 0.000 & 0.092 & 0.003 & 0.008 & 0.113 \\
$\begin{array}{c}\text { Unemployed } \\
\text { Inactive }\end{array}$ & 0.014 & 0.021 & 0.003 & 0.005 & 0.046 & 0.027 & 0.116 \\
\hline
\end{tabular}

${ }^{10}$ Inactivity also includes discouraged workers. 
Table 3: Yearly transitions individuals initially in low-wage employment (ECHP-Spain, 1995-2001)

\begin{tabular}{cccccc}
\hline $\begin{array}{c}\text { Low } \\
\text { pay }\end{array}$ & $\begin{array}{c}\text { No low } \\
\text { pay }\end{array}$ & $\begin{array}{c}\text { Employee } \\
<15 \mathrm{~h}\end{array}$ & $\begin{array}{c}\text { Self-employed } \\
\text { +Unpaid family work }\end{array}$ & Unemployed & $\begin{array}{c}\text { Inactive }+ \\
\text { Discouraged } \\
\text { workers }\end{array}$ \\
\hline 0.403 & 0.333 & 0.019 & 0.033 & 0.125 & 0.087 \\
\hline
\end{tabular}

As pointed out before, for the purpose of this paper I select wage and salary workers working more than 15 hours per week. And I analyze the probability of leaving a low pay situation conditional on being initially low-paid. Table 3 presents transitions out of low-wage employment for the whole sample of wage and salary workers working more than 15 hours per week.

Table 4a: Descriptive Statistics (Selection Equation)

\begin{tabular}{|c|c|c|c|c|c|c|}
\hline \multirow[t]{2}{*}{ Variables } & \multicolumn{2}{|c|}{ Total sample } & \multicolumn{2}{|c|}{$\begin{array}{c}\text { No low pay } \\
(83.9 \%)\end{array}$} & \multicolumn{2}{|c|}{$\begin{array}{l}\text { Low pay } \\
(16.1 \%)\end{array}$} \\
\hline & Mean & St.Dev & Mean & St.Dev & Mean & St.Dev \\
\hline Female & 0.382 & 0.486 & 0.357 & 0.479 & 0.515 & 0.500 \\
\hline Married & 0.560 & 0.496 & 0.593 & 0.491 & 0.394 & 0.489 \\
\hline Responsible for accommodation & 0.370 & 0.483 & 0.401 & 0.490 & 0.210 & 0.408 \\
\hline \multicolumn{7}{|l|}{ Age } \\
\hline $16-29$ & 0.390 & 0.488 & 0.355 & 0.479 & 0.569 & 0.495 \\
\hline $30-49$ & 0.526 & 0.499 & 0.560 & 0.496 & 0.347 & 0.476 \\
\hline $50-64$ & 0.084 & 0.278 & 0.084 & 0.278 & 0.084 & 0.277 \\
\hline \multicolumn{7}{|l|}{ Education } \\
\hline Primary & 0.486 & 0.500 & 0.448 & 0.497 & 0.682 & 0.466 \\
\hline Secondary & 0.214 & 0.410 & 0.216 & 0.411 & 0.202 & 0.402 \\
\hline Tertiary & 0.300 & 0.458 & 0.335 & 0.472 & 0.115 & 0.319 \\
\hline Temporary contract & 0.467 & 0.499 & 0.415 & 0.493 & 0.737 & 0.440 \\
\hline Part-time employment & 0.079 & 0.269 & 0.074 & 0.262 & 0.102 & 0.303 \\
\hline First job & 0.224 & 0.417 & 0.215 & 0.411 & 0.275 & 0.446 \\
\hline On-the-job training & 0.253 & 0.435 & 0.287 & 0.453 & 0.075 & 0.264 \\
\hline $\begin{array}{c}\text { Previously unemployed (>=1 year) } \\
\text { Occupation }\end{array}$ & 0.231 & 0.421 & 0.223 & 0.416 & 0.273 & 0.445 \\
\hline Legislators. senior officials and managers & 0.019 & 0.136 & 0.022 & 0.147 & 0.002 & 0.043 \\
\hline Professionals & 0.115 & 0.319 & 0.135 & 0.342 & 0.010 & 0.099 \\
\hline Technicians and associate professionals & 0.094 & 0.292 & 0.105 & 0.306 & 0.039 & 0.193 \\
\hline Clerks & 0.109 & 0.312 & 0.117 & 0.322 & 0.066 & 0.248 \\
\hline Service workers. shop and market sales workers & 0.160 & 0.366 & 0.138 & 0.345 & 0.272 & 0.445 \\
\hline Skilled agricultural and fishery workers & 0.016 & 0.126 & 0.012 & 0.111 & 0.035 & 0.184 \\
\hline Craft and related trade workers & 0.188 & 0.391 & 0.195 & 0.396 & 0.153 & 0.360 \\
\hline Plant and machine operators and assemblers & 0.095 & 0.293 & 0.097 & 0.296 & 0.084 & 0.277 \\
\hline Elementary occupations & 0.187 & 0.390 & 0.161 & 0.368 & 0.318 & 0.466 \\
\hline $\mathrm{N}$ & \multicolumn{6}{|c|}{18595} \\
\hline
\end{tabular}


Table 4b. Descriptive Statistics (Main equation)

\begin{tabular}{|c|c|c|c|c|c|c|}
\hline & \multicolumn{2}{|c|}{ Total Sample } & \multicolumn{2}{|c|}{$\mathrm{y}_{\mathrm{i} 2}=0(48.3 \%)$} & \multicolumn{2}{|c|}{$\mathrm{y}_{\mathrm{i} 2}=1(51.7)$} \\
\hline & Mean & St.Dev & Mean & St..Dev & Mean & St.Dev \\
\hline Female & 0.487 & 0.500 & 0.567 & 0.496 & 0.412 & 0.492 \\
\hline \multicolumn{7}{|l|}{ Age } \\
\hline $16-29$ & 0.561 & 0.496 & 0.540 & 0.499 & 0.581 & 0.494 \\
\hline $30-49$ & 0.365 & 0.482 & 0.366 & 0.482 & 0.364 & 0.482 \\
\hline $50-64$ & 0.074 & 0.262 & 0.094 & 0.292 & 0.055 & 0.227 \\
\hline \multicolumn{7}{|l|}{ Education } \\
\hline Primary & 0.675 & 0.468 & 0.734 & 0.442 & 0.621 & 0.485 \\
\hline Secondary & 0.201 & 0.401 & 0.186 & 0.390 & 0.214 & 0.411 \\
\hline Tertiary & 0.123 & 0.328 & 0.077 & 0.267 & 0.165 & 0.371 \\
\hline \multicolumn{7}{|l|}{ Switching contract and/or employers } \\
\hline Stayer P-P & 0.244 & 0.429 & 0.239 & 0.427 & 0.248 & 0.432 \\
\hline Stayer P-T & 0.036 & 0.186 & 0.044 & 0.205 & 0.028 & 0.166 \\
\hline Stayer T-T & 0.274 & 0.446 & 0.304 & 0.460 & 0.246 & 0.431 \\
\hline Stayer T-P & 0.156 & 0.363 & 0.138 & 0.345 & 0.173 & 0.379 \\
\hline Mover P-P & 0.007 & 0.084 & 0.007 & 0.082 & 0.007 & 0.085 \\
\hline Mover P-T & 0.035 & 0.183 & 0.036 & 0.186 & 0.034 & 0.180 \\
\hline Mover T-T & 0.231 & 0.421 & 0.219 & 0.414 & 0.242 & 0.428 \\
\hline Mover T-P & 0.018 & 0.133 & 0.013 & 0.115 & 0.022 & 0.147 \\
\hline First job & 0.258 & 0.438 & 0.256 & 0.437 & 0.259 & 0.439 \\
\hline On-the-job training & 0.079 & 0.270 & 0.056 & 0.230 & 0.101 & 0.301 \\
\hline \multicolumn{7}{|l|}{ Type of firm } \\
\hline Public & 0.051 & 0.220 & 0.046 & 0.210 & 0.056 & 0.229 \\
\hline Private $(<50)$ & 0.782 & 0.413 & 0.816 & 0.388 & 0.750 & 0.433 \\
\hline Private $(50-500)$ & 0.113 & 0.317 & 0.104 & 0.306 & 0.121 & 0.326 \\
\hline Private $(>500)$ & 0.026 & 0.159 & 0.013 & 0.115 & 0.038 & 0.191 \\
\hline Job duration $>=3$ years & 0.263 & 0.440 & 0.272 & 0.445 & 0.254 & 0.436 \\
\hline \multicolumn{7}{|l|}{ Occupation } \\
\hline Legislators. senior officials and managers & 0.002 & 0.040 & 0.001 & 0.034 & 0.002 & 0.046 \\
\hline Professionals & 0.008 & 0.087 & 0.003 & 0.058 & 0.012 & 0.107 \\
\hline Technicians and associate professionals & 0.041 & 0.199 & 0.031 & 0.175 & 0.050 & 0.219 \\
\hline Clerks & 0.072 & 0.258 & 0.056 & 0.230 & 0.086 & 0.281 \\
\hline Service workers. shop and market sales workers & 0.278 & 0.448 & 0.301 & 0.459 & 0.256 & 0.437 \\
\hline Skilled agricultural and fishery workers & 0.034 & 0.180 & 0.044 & 0.205 & 0.024 & 0.154 \\
\hline Craft and related trade workers & 0.161 & 0.367 & 0.143 & 0.350 & 0.178 & 0.382 \\
\hline Plant and machine operators and assemblers & 0.097 & 0.295 & 0.080 & 0.271 & 0.112 & 0.316 \\
\hline Elementary occupations & 0.299 & 0.458 & 0.336 & 0.472 & 0.265 & 0.441 \\
\hline $\mathrm{N}$ & \multicolumn{6}{|c|}{1679} \\
\hline
\end{tabular}

Tables $4 \mathrm{a}$ and $4 \mathrm{~b}$ contain some descriptive statistics (mean and standard deviation) for the selected sample. In Table 4a I present the descriptive statistics for the variables included as explanatory factors in the selection equation (probability of being low-paid). The descriptive 
analysis is made for the total sample ${ }^{11}$, and separately for individuals in low-wage employment and those earning more than the low pay threshold. When comparing the subsamples of individuals below and above the low pay threshold, clear differences can be observed in the sample means. In particular, low-wage employment is found to be more likely among females, young workers, workers with lower levels of education, and workers employed on a temporary basis. Furthermore, the risk of lowwage employment seems to be less likely amongst married individuals, individuals who are responsible for household accommodation and those living in a couple with dependent children. In Table $4 \mathrm{~b}$ I present the descriptive statistics (mean and standard deviation) for explanatory factors included in the main equation (probability of leaving a low-paid job). As can be observed, around half of the sample moves to a better paid job at some moment during the period under analysis. For the rest of the sample, in contrast, low-wage employment seems to be a more long-lasting phenomenon. The descriptive statistics suggest that leaving a low pay situation seems to be more likely among males, young workers, workers with higher levels of education, workers switching into permanent employment, and workers receiving on-the-job training.

The results obtained from the Heckman probit model are reported in Tables 5a and 5b. These results confirm most of the results derived from the descriptive statistics. Table 5 a presents the determinants of being in a low-paid job (selection equation), while Table 5b shows the factors determining the probability of leaving a low pay situation (main equation). ${ }^{12}$ Regarding the determinants of low-wage employment, the main results can be summarized as follows. I find a remarkably higher incidence of low-wage employment amongst females and the youngest workers. Females present a probability of being low-paid of 4.7 percentage points higher than their male counterparts. And for workers older than 30 years old, the probability of being in low-wage employment is reduced by around 2.2 percentage points with respect to the reference category. Furthermore, the risk of low-wage employment is significantly lower amongst married, individuals responsible for household accommodation and those living in a couple with dependent children. As expected, education exerts a negative and significant effect on the individual likelihood of being low-paid. In particular, having tertiary education completed reduced the risk of low-wage employment by almost 4

11 The total sample consists of wage and salary workers aged between 16 and 64 years and working more than 15 hours per week.

12 To better understand the results, Table $5 \mathrm{~b}$ ) shows marginal effects instead of coefficients. 
percentage points compared to those with just primary education completed. In contrast, being employed on a temporary basis increases the risk of being low-paid by 4.5 percentage points. Furthermore, the econometric analysis reveals that working part-time significantly reduces the probability of being in a low-paid job by 3.4 percentage points, and the same is observed among those workers who receive on-the-job training for whom the risk of low pay is reduced by 4.6 percentage points. In contrast, low-wage employment is found to be more likely among those workers who are in their first job. Finally, the results reveal that low-wage employment is more likely among certain types of occupations, mainly skilled agricultural and fishery workers, and service workers and shop and market sales workers for whom the risk of low pay is, respectively, 16.5 and 8.2 percentage points higher than for the reference category (clerks).

\section{Table 5a. Probit model for the probability of being low-paid} (selection equation)

\begin{tabular}{|c|c|c|}
\hline Variable & $\begin{array}{c}\text { Marginal } \\
\text { Effects }\end{array}$ & $\mathrm{t}$ \\
\hline Female & 0.047 & 10.34 \\
\hline Married & -0.026 & -6.33 \\
\hline Responsible for accommodation & -0.011 & -2.88 \\
\hline Couple with dependent children & -0.007 & -2.24 \\
\hline $\begin{array}{c}\text { Age } \\
30-49\end{array}$ & -0.021 & -5.28 \\
\hline $50-64$ & -0.020 & -3.79 \\
\hline Education & & \\
\hline Secondary & -0.025 & -7.01 \\
\hline Tertiary & -0.038 & -8.68 \\
\hline Temporary contract & 0.045 & 11.66 \\
\hline Part-time employment & -0.034 & -9.31 \\
\hline First job & 0.022 & 4.57 \\
\hline On-the-job training & -0.046 & -12.62 \\
\hline Previously unemployed ( $>=1$ year) & 0.013 & 3.16 \\
\hline Occupation & & \\
\hline Legislators. senior officials and managers & -0.038 & -3.27 \\
\hline Professionals & -0.058 & -12.83 \\
\hline Technicians and associate professionals & -0.001 & -0.09 \\
\hline Service workers and shop and market sales workers & 0.082 & 7.84 \\
\hline Skilled agricultural and fishery workers & 0.165 & 5.58 \\
\hline Craft and related trade workers & 0.017 & 2.18 \\
\hline Plant and machine operators and assemblers & 0.045 & 4.12 \\
\hline Elementary occupations & 0.059 & 6.18 \\
\hline $\mathrm{N}$ & \multicolumn{2}{|c|}{18595} \\
\hline Log likelihood & \multicolumn{2}{|c|}{-6271} \\
\hline
\end{tabular}




\section{Table 5b. Heckman probit selection model for the probability of} leaving a low-paid job

\begin{tabular}{|c|c|c|}
\hline & Marginal Effects & $\mathrm{t}$ \\
\hline Female & -0.167 & -6.65 \\
\hline \multicolumn{3}{|l|}{ Age } \\
\hline $30-49$ & -0.014 & -0.50 \\
\hline $50-64$ & -0.107 & -2.08 \\
\hline \multicolumn{3}{|l|}{ Education } \\
\hline Secondary & 0.057 & 1.99 \\
\hline Tertiary & 0.180 & 5.14 \\
\hline \multirow{2}{*}{\multicolumn{3}{|c|}{$\begin{array}{c}\text { Switching contract and/or employers } \\
\text { Stayer P-P }\end{array}$}} \\
\hline & & \\
\hline Stayer P-T & -0.067 & -1.05 \\
\hline Stayer T-T & 0.025 & 0.57 \\
\hline Stayer T-P & 0.115 & 2.42 \\
\hline Mover P-P & -0.053 & -0.39 \\
\hline Mover P-T & -0.009 & -0.14 \\
\hline Mover T-T & 0.089 & 1.95 \\
\hline Mover T-P & 0.190 & 2.04 \\
\hline First job & -0.012 & -0.44 \\
\hline On-the-job training & 0.068 & 1.58 \\
\hline \multicolumn{3}{|l|}{ Type of firm } \\
\hline \multirow{2}{*}{\multicolumn{3}{|c|}{ Private $(<50)$}} \\
\hline & & \\
\hline Private $(50-500)$ & 0.056 & 1.65 \\
\hline Private $(>500)$ & 0.183 & 3.33 \\
\hline Job Duration $>=3$ years & 0.011 & 0.38 \\
\hline \multicolumn{3}{|l|}{ Occupation } \\
\hline Legislators. senior officials and managers & -0.185 & -0.62 \\
\hline Professionals & 0.005 & 0.03 \\
\hline Technicians and associate professionals & -0.072 & -1.00 \\
\hline \multicolumn{3}{|l|}{ Clerks } \\
\hline Service workers and shop and market sales workers & -0.138 & -2.83 \\
\hline Skilled agricultural and fishery workers & -0.311 & -4.00 \\
\hline Craft and related trade workers & -0.079 & -1.46 \\
\hline Plant and machine operators and assemblers & -0.074 & -1.23 \\
\hline Elementary occupations & -0.138 & -2.70 \\
\hline$\rho$ & 0.492 & 2.30 \\
\hline $\mathrm{N}$ & 1679 & \\
\hline Log likelihood & -6271 & \\
\hline
\end{tabular}

Table $5 \mathrm{~b}$ presents the estimations results for the probability of leaving a low-paid job. As it can be observed females and old workers are significantly less likely to move to better paid jobs. In particular, being female reduces the likelihood of getting a better paid job by more than 16 percentage points, while for workers aged between 50-64 years old the 
probability is reduced by more than 10 percentage points. In contrast, having tertiary education exerts a positive and significant effect on the probability of moving to a job above the low pay threshold, increasing this probability by 18 percentage points with respect to the reference category. The results also reveal that there are certain types of occupations for which escaping from a low pay situation is significantly less likely. This is the case of "service workers and shop and market sales workers", "skilled agricultural and fishery workers" and "elementary occupations" who exhibit, respectively, a probability of moving to a better paid job of 13.8 , 31.1 and 13.8 percentage points lower than those in the reference category ("clerks")

Changing job and switching into permanent employment positively affect the likelihood of getting a better paid job. As can be observed, changing from temporary to permanent contract while continuing with the same employer increases this probability by around 11 percentage points, while the increase is of 19 percentage points when the individual also changes employer. Figure A9 presents the predicted probability of leaving a low-paid job, conditional on being initially in a low pay situation, for the eight categories that combine job mobility and changes in the contractual arrangement. As can be observed, the highest probability corresponds to those switching into permanent employment and changing employer at the same time. The second position is occupied by those switching into permanent but remaining with the same employer. In contrast, the lowest probability is observed among those who continue employed on a permanent basis and switch into temporary employment.

\section{Concluding remarks}

In this paper I have analysed the patterns of low-wage employment in Spain using micro data at the individual level extracted from the European Community Household Panel for the period 1995-2001.

First, I analysed how low-wage employment has evolved over the period under analysis, looking at different individual and job characteristics. Then, I carried out a more-in-depth analysis on the determinants of the probability of leaving a low-wage employment towards a better paid job. Since the possibility that being low-paid is not exogenous, and that this could lead to biased results, I estimated a Heckman probit selection model that allowed me to account for a problem of sample selection. Results reveal that switching into permanent employment either when continuing with the current employer or when 
changing employer significantly increases the probability of getting a better paid job.

\section{References}

Arai, M., Asplund, R., and Barth, E. (1998): "Low Pay, A Matter of Occupation" in R. Asplund, P.J. Sloane, and I. Theodossious (eds.), Low Pay and Earnings Mobility in Europe, Aldershot: Edward Elgar.

Asplund, R., Sloane, P., and Theodossiou, I. (1998): Low pay and Earnings Mobility in Europe. Edward Elgard (eds). Cheltenham, UK, Northampton, MA, USA.

Asplund, R., Bingley, P., and Westergård-Nielsen, N. (1998): "Wage Mobility for Low-Wage Earners in Denmark and Finland", in R. Asplund, P.J. Sloane, and I. Theodossious (eds.), Low Pay and Earnings Mobility in Europe, Aldershot: Edward Elgar.

Bartel, A., and Borjas, G. (1981): "Wage Growth and Job Turnover: An Empirical Analysis", in S. Rosen, ed, Studies in Labor Markets. Chicago: University of Chicago Press, pp. 65-90.

Bazen, S., Salverda, W., and Gregory, M. (1999): Low wage employment in Europe. Edward Elgard (eds). Cheltenham, UK, Northampton, MA, USA.

Becker, G. (1962): "Investment in Human Capital: A Theoretical Analysis”. Journal of Political Economy, 70(1) pp. 9-49.

Bentolila, S., and Dolado, J.J. (1994) "Labor Flexibility and Wages: Lessons from Spain” Economic Policy 18, pp. 53-99.

Burdett, K. (1978) "A Theory of Employee Job Search and Quit Rates". American Economic Review 68(1), pp. 212-220.

Cappellari, L. (2004). "Earnings Mobility among Italian Low Paid Workers". IZA, Discussion Paper Nº 1068.

Card, D., and Krueger, A.B. (1995). Myth and Measurement: The New Economics of the Minimum Wage. Princenton, NJ: Princenton University Press. 
Castillo, S., and Toharia, L. (1993). "Las Desigualdades en el Trabajo". I Simposio sobre Igualdad y Distribución de la Renta y Riqueza. Argentaria, vol. IV, pp. 7-88.

Centre d'Etudes sur le Revenu et les Coûts (CERC) (1991), Les bas salaries dans les pays members la Communanté Européenne, La Documentation Francaise, N 101. Paris.

Davia, M.A. (2005) "Job Mobility and Wage Mobility at the Beginning of the Working Career: A Comparative View Across Europe” ISER Working Papers, Number 2005-03.

Davia, M.A., and Hernaz, V. (2004). "Temporary Employment and Segmentation in the Spanish Labour Market: An Empirical Analysis through the Study of Wage Differentials". Spanish Economic Review, vol 6 (4), pp. 291-318.

De la Rica, S., and Felgueroso, F. (1999). "Wage Differentials between Permanent and Temporal Workers: Further evidence". Mimeo. University of País Vasco and University of Oviedo.

Dickens, R. (2000). "Caught in a trap? Wage Mobility in Great Britain: 1975-1994”. Economica, 67, pp. 477-97.

Dolado, J., Kramarz, F., Machin, S., Manning, A., Margoli, D., and Teulings, C. (1996). "The Economic Impact of Minimum Wages in Europe". Economic Policy 33: 317-72.

European Community (2004). "Labour Market Transitions and Advancement: Temporary Employment and Low Pay in Europe", chap 4, in Employment in Europe, 2004.

Fernie, S., and Metcalf, D. (1996). "Low Pay and Minimum Wages: The British Evidence". Special Report, Centre for Economic Performance, London School of Economics.

Gosling, A. et al. (1997). The Dynamics of Low Pay and Unemployment in Early 1990s Britain, London: Institute for Fiscal Studies.

Gregory, M., and Elias, P. (1994). "Earnings Transitions of the Low-Paid in Britain, 1976-91: A Longitudinal Study". International Journal of 
Manpower, 15 (2-3), 170-88.

Hirsch, F. (1995): “Social Limits to Growth”. London, Routledge.

Jimeno, J.F., and Toharia, L. (1993): "The Effects of Fixed-Term Employment on Wages: Theory and Evidence from Spain" Investigaciones Económicas, 17 (3), pp. 475-94.

Jovanovic, B. (1979): "Job Matching and the Theory of Turnover". Journal of Political Economy, 87, pp. 972-990.

Keith, K., and McWilliams, A. (1997): "Job Mobility and Gender-Based Wage Growth Differentials”. Economic Inquiry, 35(2), pp 320-33.

Keith, K., and McWilliams, A. (1999): "The Returns to Mobility and Job Search by Gender". Industrial and Labor Relations Review, April 1999, 52(3), pp. 460-77.

Loprest, P.J. (1992): "Gender Differences in Wage Growth and Job Mobility". American Economic Review, 82(2), pp. 526-32.

Lucifora, C., and Salverda, W. (1998): Policies for Low Wage Employment and Social Exclusion. European Low-wage Employment Research Network. FrancoAngeli s.r.l, Milano, Italy.

Lucifora, C., McKnight, A., and Salverda, W. (2005): "Low-wage employment in Europe: a review of the evidence". Socio-Economic Review (2005) 3: 259-292.

Machin, S., and Manning, A. (1996): "Employment and the Introduction of Minimum Wage in Britain”. Economic Journal 106(May): 667-76.

Marx, I., and Salverda, W. (2005): Low-wage Employment in Europe. Acco.

Mincer, J. (1986): "Wage Changes in Job Changes", in R. G Ehrenberg, ed. Research in Labor Economics, vol 8 (Part A). London: JAI Press Inc., pp. 171-97.

OECD (1996, 1997, 1998): Employment Outlook, Paris: Organisation for Economic Co-operation and Development.

Parsons, D.O. (1972): "Specific Human Capital: An Application to Quit 
Rates and Layoff Rates”. Journal of Political Economy, 80, pp. 1120-1143.

Pérez, S., and Hidalgo, A. (1999): "Los Salarios en España". Fundación Argentaria-Visor. Programa de Economía Familiar, colección Economía Española, vol XII.

Salverda, W., Lucifora, C., and Nolan, B. (2000). Policy Measures for LowWage Employment in Europe. Edward Elgard (eds). Cheltenham, UK, Northampton, MA, USA.

Schechter, H.B. (1993). The Global Economic Mismatch:High Technology and Low Pay. London: Praeger.

Shaheed, Z. (1994): "Minimum Wages and Low Pay: An ILO Perspective". International Journal of Manpower 15(2/3): 49-61.

Simón, H., Fernández, M., and Meixide, A. (2004): "Empleo de salarios bajos y pobreza en España”. Revista de Economía Laboral 1 (2004), pp 7688.

Shorrocks, A. (1978): “The measurement of mobility". Econometrica, 46: 1013-1024.

Sloane, P. J., and Theodossiou, I. (1998): "An Econometric Analysis of Low Pay and Earnings Mobility in Britain" in R. Asplund, P.J. Sloane, and I. Theodossious (eds.), Low Pay and Earnings Mobility in Europe, Aldershot: Edward Elgar.

Stewart, M.B. (1999): "Low Pay, No Pay Dynamics" in Persistent Poverty and Lifetime Inequality: The Evidence, Centre for Analysis of Social Exclusion, London School of Economics, Report n ${ }^{\circ} 5$.

Stewart, M.B., and Swaffield, J.K. (1999): "Low Pay Dynamics and Transition Probabilities". Economica, 66; pp. 23-42.

Topel, R.H., and Ward, M.P. (1992): "Job Mobility and the Careers of Young Men”. Quarterly Journal of Economics, 107(2), pp. 439-79.

Van Opstal, R., Waaijers, R., and Wiggers, G. (1998): "Wage Growth of Low- and High-Skilled Workers in the Netherlands" in R. Asplund, P.J. Sloane, and I. Theodossious (eds.), Low Pay and Earnings Mobility in Europe, Aldershot: Edward Elgar. 


\section{Appendix}

\section{A.1. Characteristics of low-paid workers}

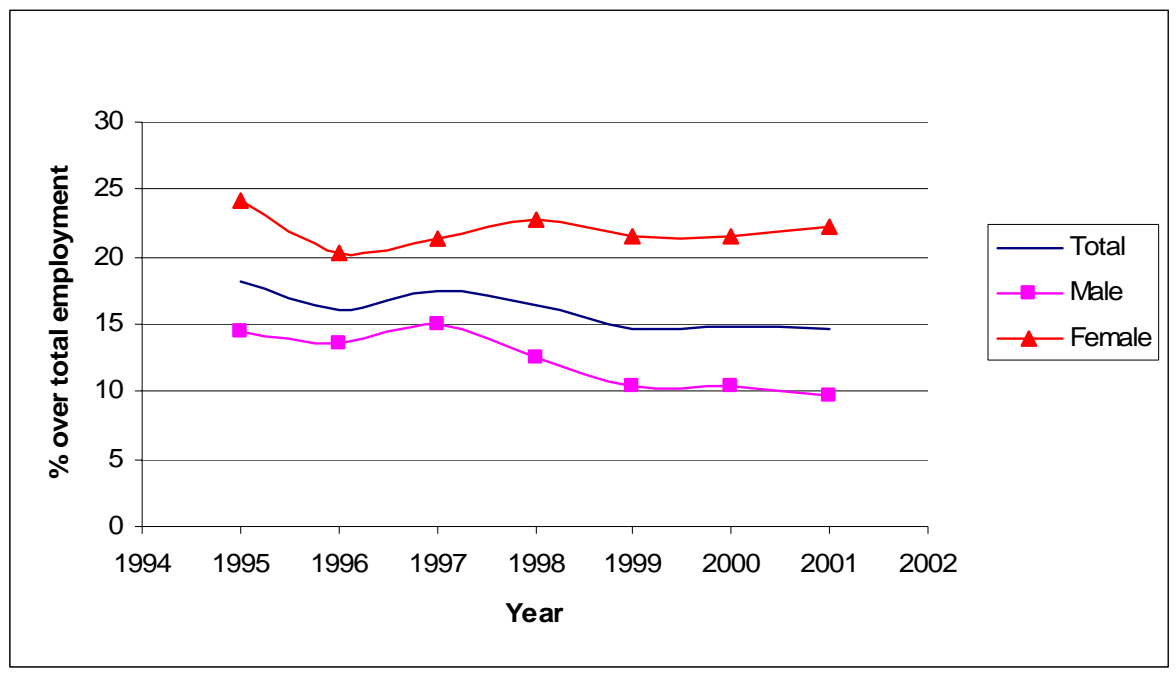

Figure A1: Evolution of low-wage employment by gender

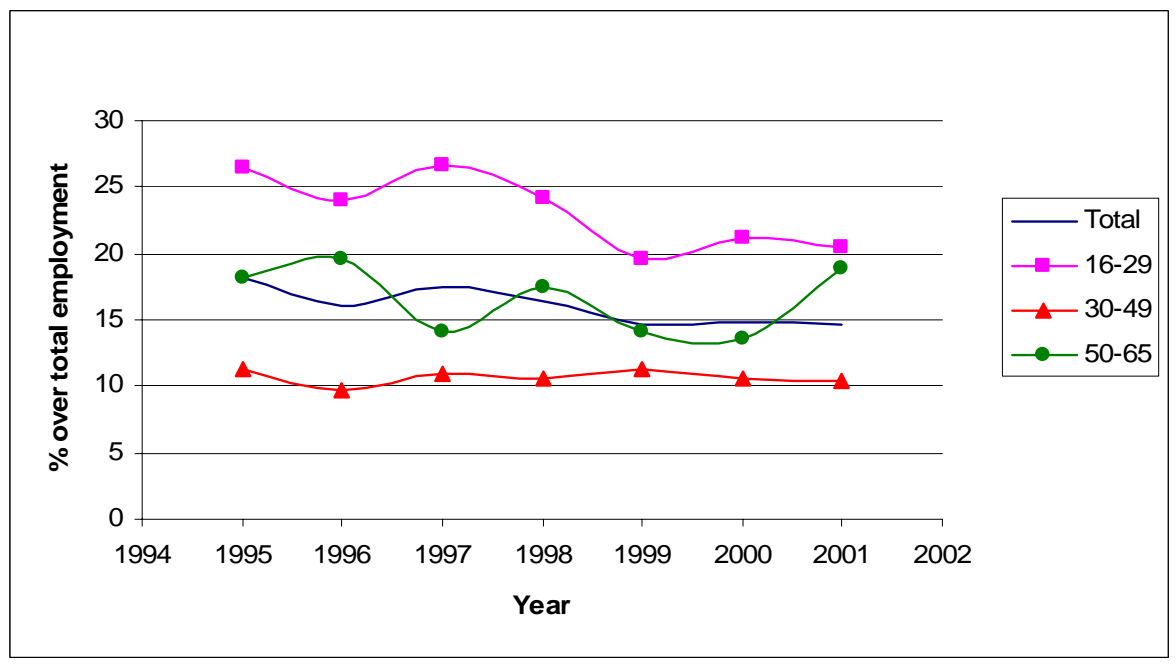

Figure A2: Evolution of low-wage employment by age 


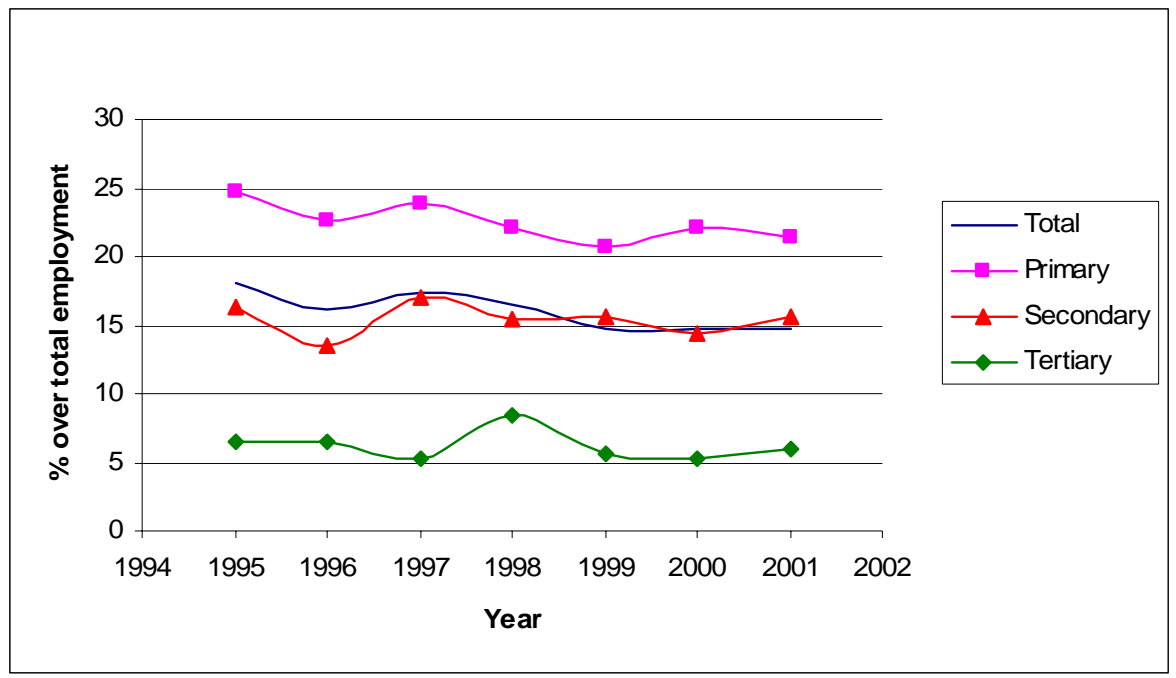

Figure A3: Evolution of low-wage employment by education

\section{A.2. Characteristics of low-paid jobs}

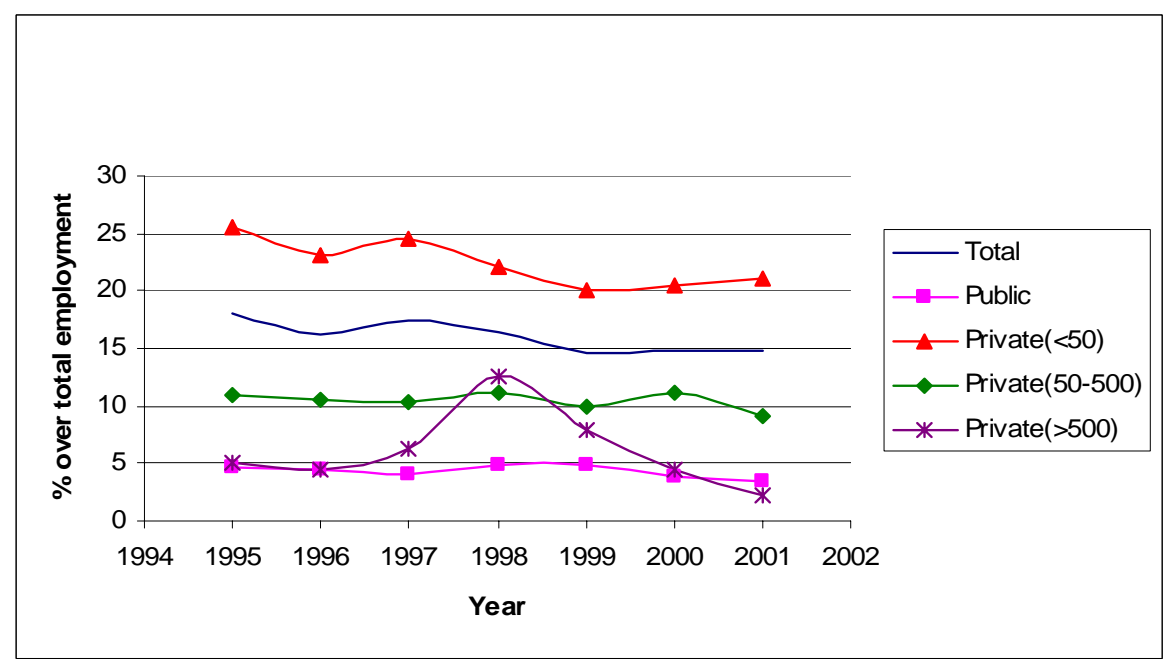

Figure A4: Evolution of low-wage employment by type of firm 


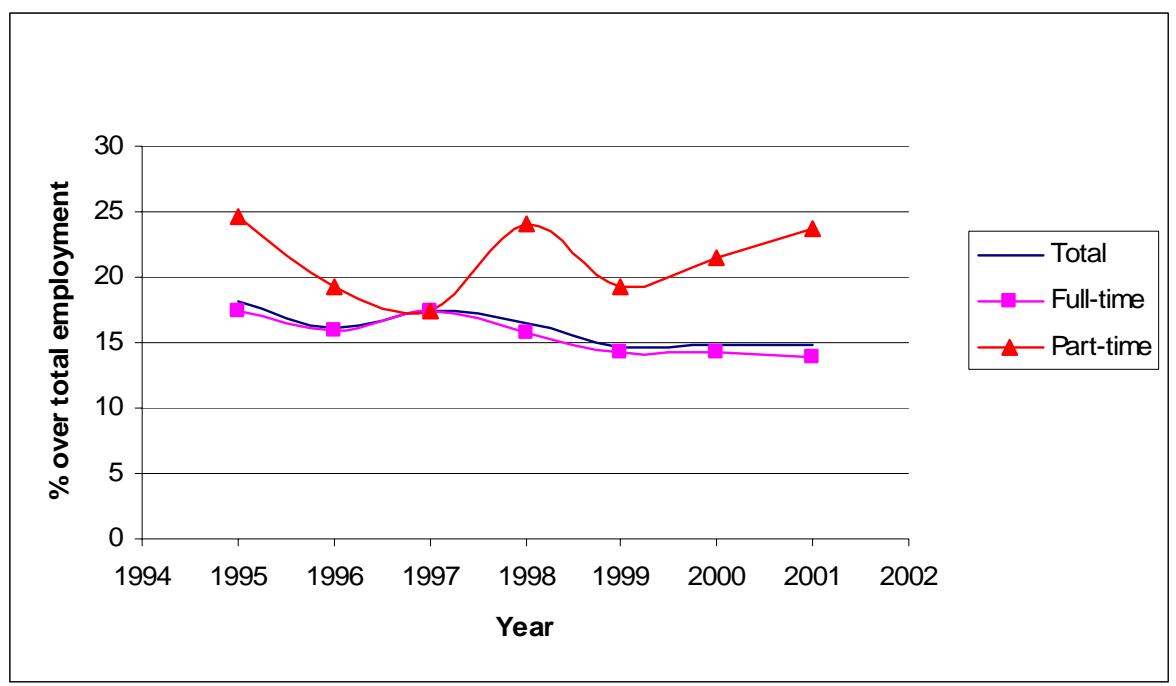

Figure A5: Evolution of low-wage employment by full/part-time

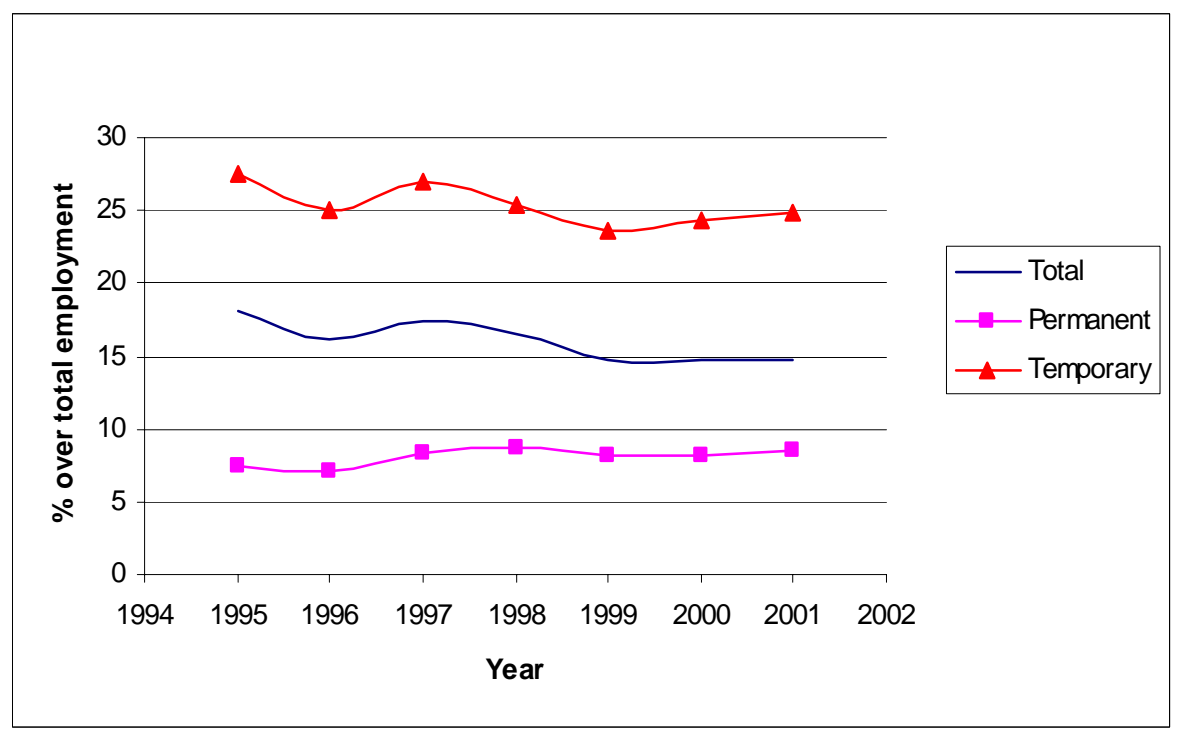

Figure A6: Evolution of low-wage employment by type of contract 


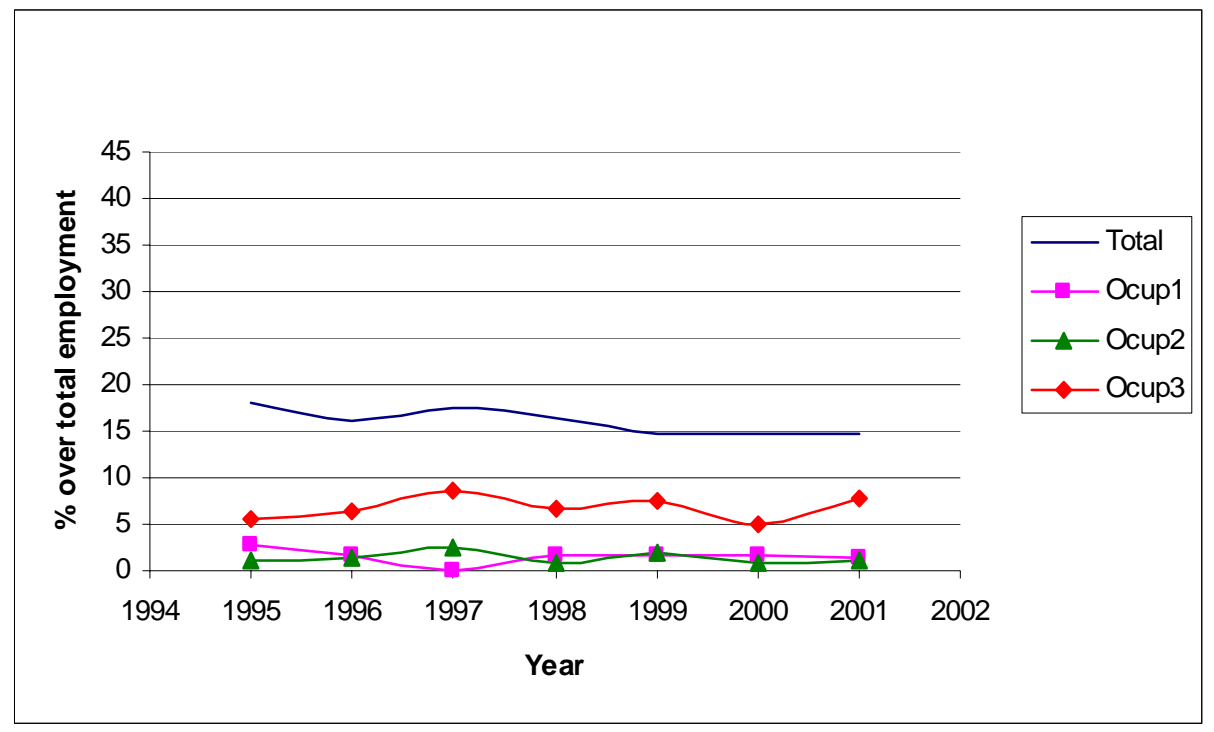

Figure A7a: Evolution of low-wage employment by occupation

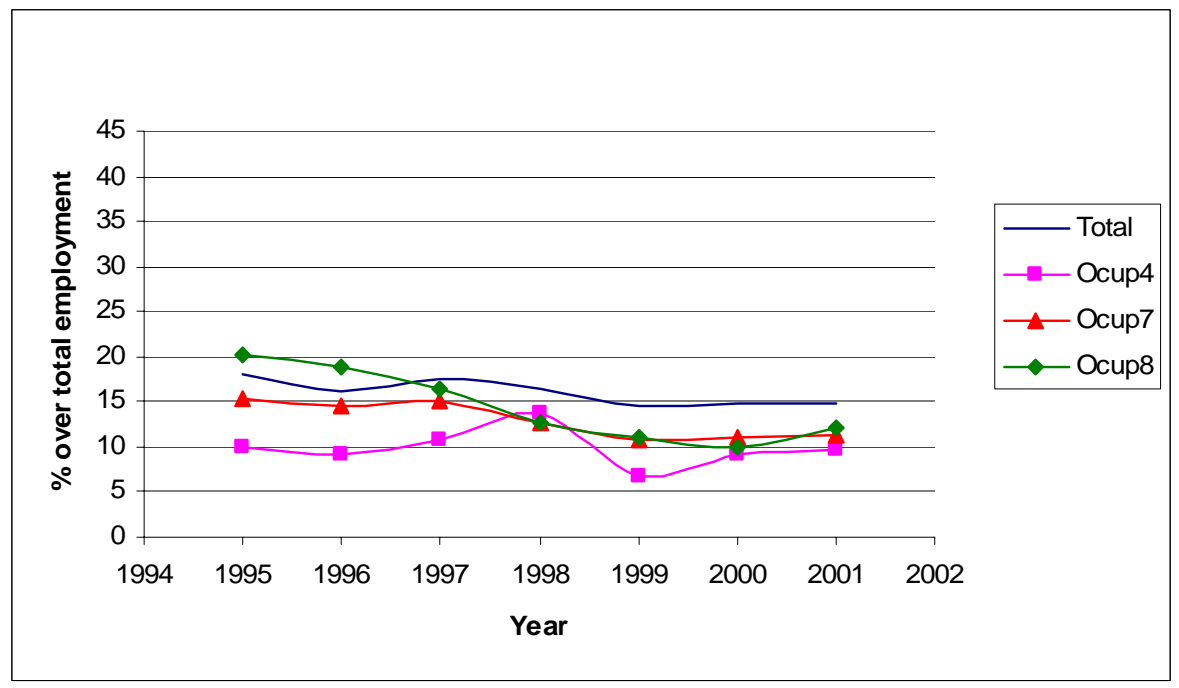

Figure A7b: Evolution of low-wage employment by occupation 


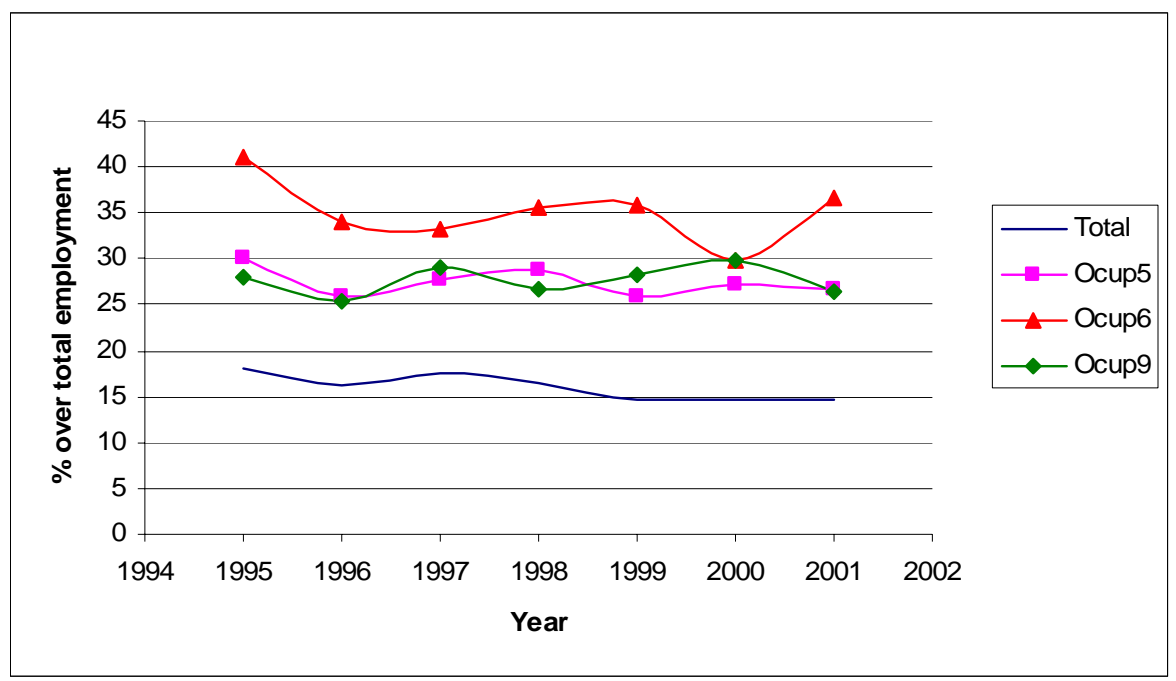

Figure A7c: Evolution of low-wage employment by occupation

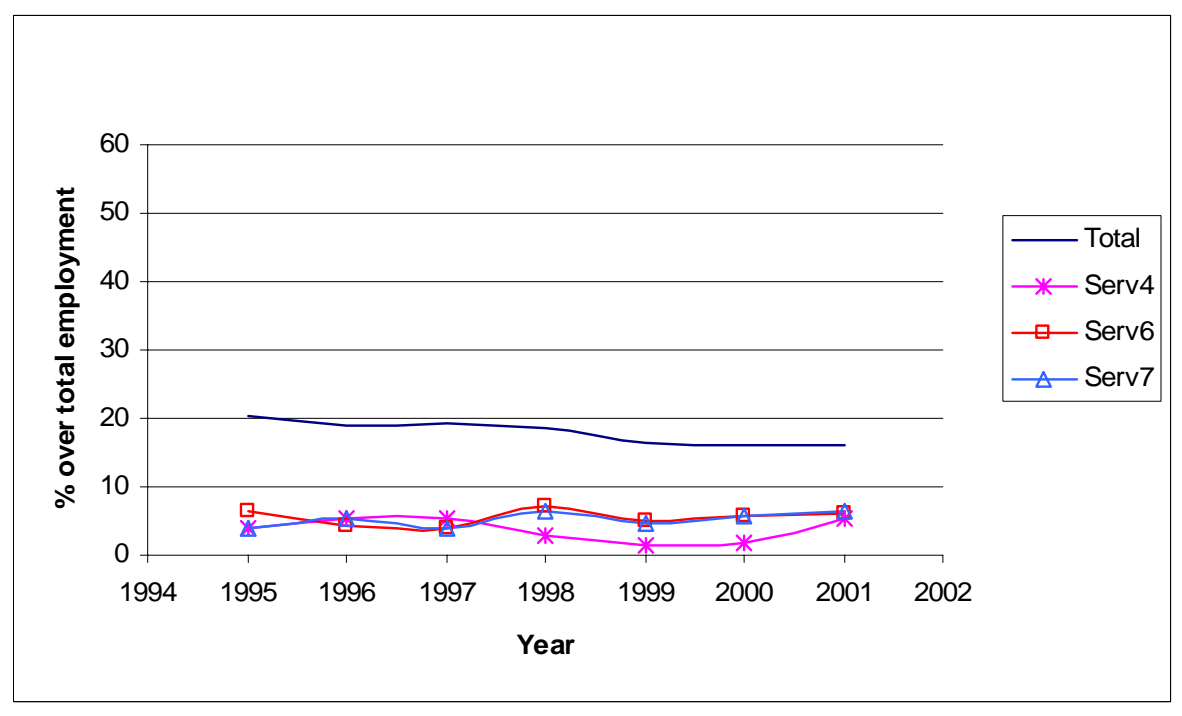

Figure A8a: Evolution of low-wage employment by industry 


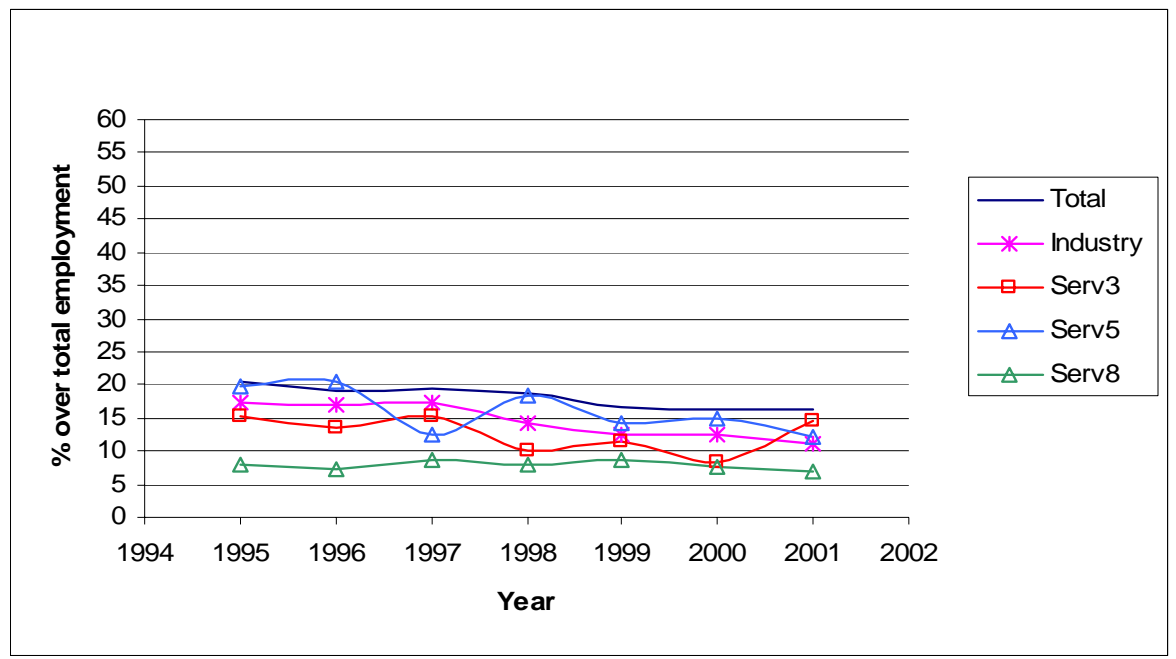

Figure A8b: Evolution of low-wage employment by industry

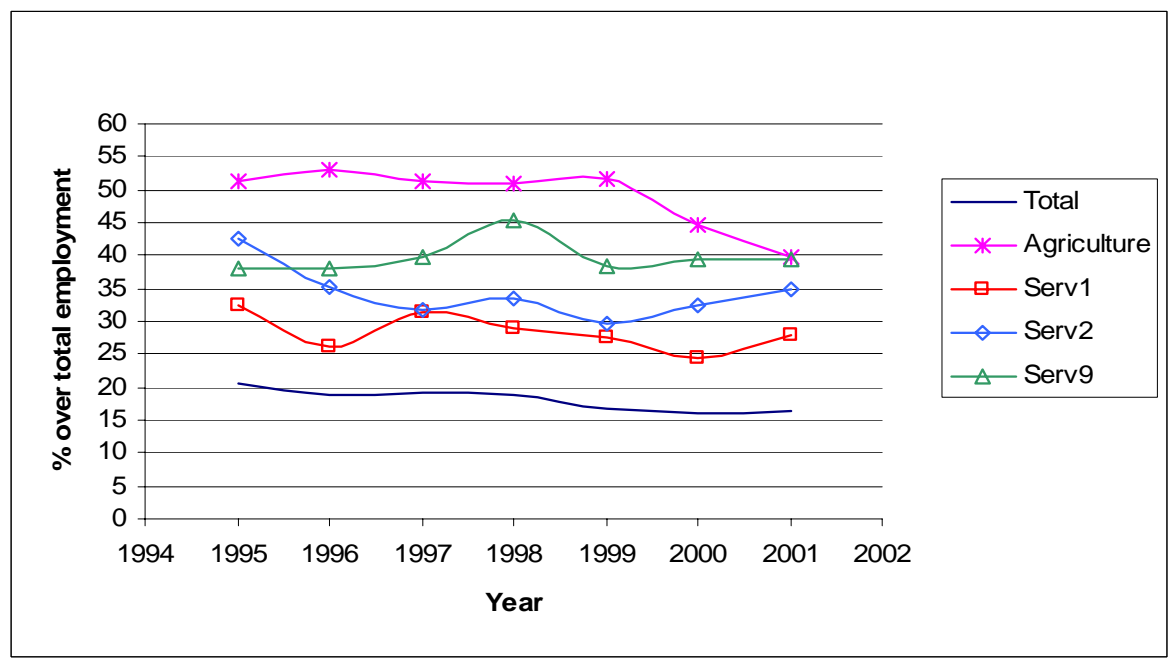

Figure A8c: Evolution of low-wage employment by industry 


\section{A.3. Econometric results}

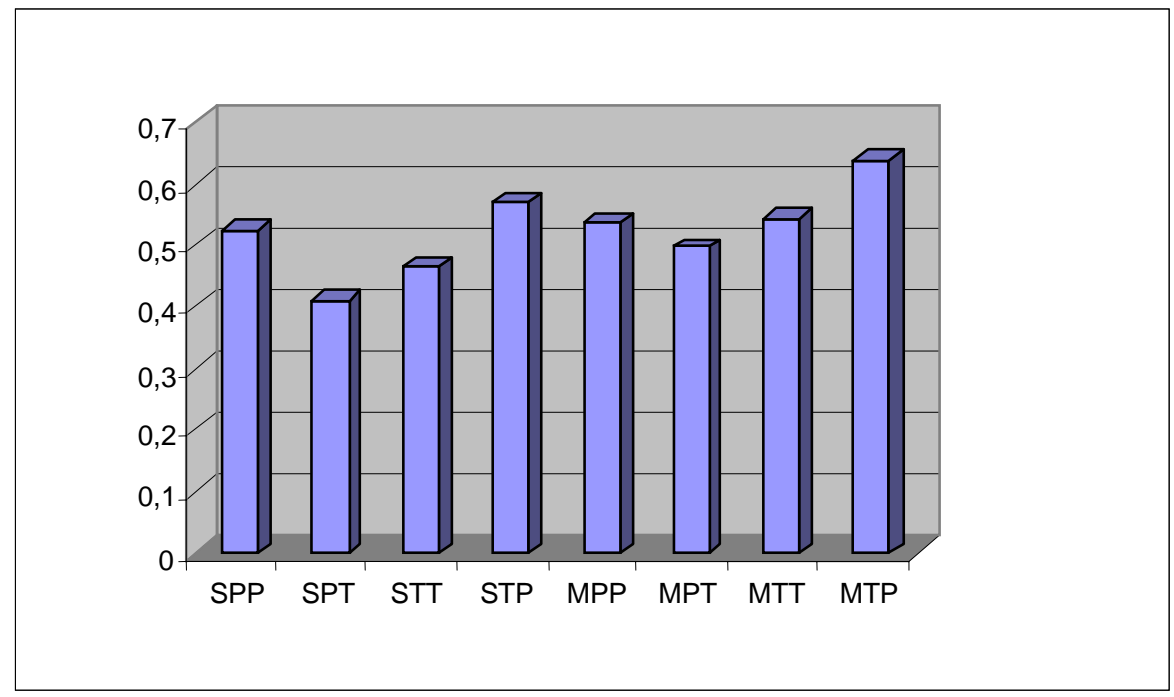

Figure A9: Pr(leaving low-paid | being initially low-paid) 